\title{
Forgotten Hispano-American Literature: Representation of Hispano-American Presses in Academic Libraries
}

\section{Kathia Salomé Ibacache Oliva, Javier Munoz-Diaz, Caitlin M. Berry, and Eric A. Vance}

As inclusion becomes a growing standard for universities in the United States, data extracted from OCLC suggest that university libraries in the United States build their Spanish-language collections with books purchased primarily in Spain and Mexico. This overlooks presses from 19 other Spanish-speaking countries in the Americas. This research is concerned with the representation of books published in these HispanoAmerican countries and examines the holdings of 88 university libraries. The article discusses the drawbacks in neglecting purchase of literature published in HispanoAmerican countries and the benefits of changing collection practices into a more inclusive design, including recommendations for best practices.

\section{Introduction}

The publishing industry of the 21st century is characterized by conglomerates and multinational presses. While online book vendors are competitors for these publishing houses, it is the smaller presses that have struggled to survive. Spanish-speaking countries in the Americas offer a wide variety of independent, consortia, and university presses that may benefit the Spanish-language collections of university libraries in the United States. These university libraries, however, tend to purchase most of their Spanish-language books from publishing houses in Spain and Mexico. This overlooks presses from 19 other Spanish-speaking countries in the Americas, which are collectively identified herein as Hispano-American.

This research is concerned with these 19 Hispano-American countries, whose publishers appear to have lesser representation in university libraries' collections in the United States. This article considers whether or not university libraries in the United States are adequately

Kathia Salomé Ibacache Oliva is Romance Languages Librarian and Assistant Professor at the University of Colorado; email: Kathia.Ibacache@colorado.edu. Javier Alonso Muñoz-Diaz is an Adjunct Faculty Member at the University of Denver; email: javier.munozdiaz@du.edu. Caitlin M. Berry is a PhD Student in Applied Mathematics at the University of Colorado Boulder; email: Caitlin.Berry@colorado.edu. Eric A. Vance is an Associate Professor of Applied Mathematics at the University of Colorado Boulder; email: Eric.Vance@colorado.edu. The authors would like to thank Steven and Leonardo for offering their insightful comments on acquisition practices involving foreign vendors. Steven Selleck is Manager, Searching and Ordering, and Leonardo Arellano is Acquisitions Receiving Specialist, both in Scholarly Resource Development, University Libraries, University of Colorado Boulder. (C2020 Kathia Salomé Ibacache Oliva, Javier Munoz-Diaz, Caitlin M. Berry, and Eric A. Vance, Attribution-NonCommercial (https://creativecommons.org/licenses/by-nc/4.0/) CC BY-NC. 
building Spanish-language collections that include literature published in Hispano-American countries. The term "literature" is understood for purposes of this study as a broad generic term to signify books of fiction and nonfiction, including literary criticism. This article evaluates the benefits of books published in Hispano-American countries, which may provide an array of emerging local authors, and features complete and canonical works that may be omitted by large non-Hispano-American publishers. In addition, this article hypothesizes that a "lo latinoamericano" essence may be missing when such books are published in Spain rather than a Hispano-American country (for example, a European perspective may differ from a Latin American perspective when publishing a book).

This study aims to answer the following question: Are university libraries in the United States building Spanish-language collections that properly consider literature published in Hispano-American countries? This study also includes a recommendation for best practices.

\section{Background}

University libraries build their collections based on pre-established criteria that suit the needs of individual institutions and their constituents. According to the American Library Association (ALA), selection criteria for academic libraries consider the mission, the goals, and the objectives of the given university and its departments. ${ }^{1}$ Similarly, other criteria normally used for selection are currency, accuracy, relevancy, scope, coverage, and cost. These criteria guide selectors to purchase materials that are relevant to the needs of individual departments, faculty, instructors, course curricula, and students at the undergraduate and graduate level.

ALA also advises contemplating aspects of diversity in authors and ideas within the context of a library's constituents. ${ }^{2}$ Universities that have a Spanish department or offer programs in Spanish may promote diversity by offering books published by Hispano-American presses in their respective authors' native countries. However, the presence of large multinational publishing houses is complicating the reach of publishing houses from Hispano-American countries.

Rhalee A. Hughes, former Associate Director of Publicity for the Penguin Young Readers Group, referring to the decline of unit sales and consumer demand, states that large publishing houses control the publishing domain. Even though they formerly had a convenient relationship with small independent retailers, now online vendors and national chains propel book sales. ${ }^{3}$ Moreover, Brigitte Ouvry-Vial, a researcher who studies the publishing industry, cautioning about the U.S. book business, notes that multinational groups drive 85 percent of American publishing, controlling access to books. ${ }^{4}$ Ouvry-Vial asserts that financial decisions are influencing the publishing industry in detriment to the intellectual value of books, adding that social sciences, translations, new authors, and critical essays are a financial risk factor. ${ }^{5}$

Another factor of interest is the relationship between author and publisher. Some express that authors feel neglected by large publishing houses, indicating that they compel collections with uniform characteristics that neglect to reflect the distinctiveness of an author's work. ${ }^{6}$ It is this gap in communication between author and publisher that Ouvry-Vial exemplifies by referring to the marketing value and connection with potential readers that is lost when the author is not involved in the process. ${ }^{7}$

Renowned French sociologist Pierre Bourdieu, examining the relationship between established publishing houses and smaller presses, contemplates "art and money" as a duality where some books have literary value and others offer monetary value that is imperative for 
the survival of a publishing house. ${ }^{8}$ Bourdieu's "dual character" notion goes beyond the economics of running a publishing house, also considering the nature of a book as symbolizing the love for literature and the need for profit. ${ }^{9}$ Profits, returns, and reducing costs are components in the publishing industry that have been addressed in different articles. ${ }^{10}$ Large and small publishing houses consider these elements as part of the risk of the publishing business.

Regardless, Ouvry-Vial states that small nonprofit presses continue publishing poetry, translations, and nonfiction literature, while university presses have adapted to the profit limitations of the industry by even copyrighting professors' lectures. ${ }^{11}$ While profit is indispensable to any merchandising business, the market versus cultural goods paradox, where books have cultural value, is a component that affects most books, which are considered unprofitable. Luca Pareschi, who studies the Italian publishing industry, indicates that editors from medium-sized publishing houses favor literary value and editors from smaller presses consider the "publisher's personal taste." ${ }^{12}$ Similarly, Bourdieu cites an agent who notes that smaller publishers prefer quality even if they do not sell in large numbers. ${ }^{13}$

\section{The Capital Factor}

Social theoreticians have coined two concepts that are considered in this study, cultural capital and social capital, which may have beneficial implications when building collections in university libraries. For Bourdieu, the accumulation of capital was a means for reaching a higher position in the social world..$^{14} \mathrm{He}$ understood cultural capital in three states: (1) the embodied state relating to the skills and knowledge a person has; (2) the objectified state transliterated in cultural goods such as books and other material belongings; and (3) the institutionalized state alluding to educational qualifications and credentials. Bourdieu also referred to social capital as a person's network, along with its size and power. ${ }^{15}$

C. Clayton Childress, a sociologist, suggests that publishing houses use "differential publishing strategies" to maintain cultural capital and retain economic capital. ${ }^{16}$ Nicki Lisa Cole, also a sociologist, explaining Bourdieu's perception of cultural capital as the acquisition of knowledge, behavior, and skills to ascertain social status, states that even in the 21st century we use cultural capital to "navigate the world around us."17

In terms of social capital, academic scholarship on this concept has increased in different fields during the 2000s. ${ }^{18}$ Sociologist James S. Coleman defines this concept within a functionality framework to acquire productivity driven by a "structure of relations" among multiple actors, "persons or corporate," who belong to a social structure. ${ }^{19}$ Ian Falk adds that social capital thrives with personal interactions based on trust and productive communication. ${ }^{20}$ Marina Tulin, Bram Lancee, and Beate Volker see this concept as a means to acquire resources provided by social networks that assist people in reaching benefits bestowed by their social ties. ${ }^{21}$ Moreover, building a network of trust and reciprocity is one indispensable component to building strong social capital..$^{22}$ This study will consider the value of cultural capital for university libraries in the United States, in addition to examining whether social capital could be beneficial to academic libraries for building relationships with book distributors that include Hispano-American presses.

\section{Diversity in the Academic Library}

Diversity in academic libraries has been a focus of the field for decades. ${ }^{23}$ With this in mind, Susan A. Vega García, examining African American and U.S. Latino periodical literature in 
academic libraries, foresees that "racial and ethnic materials will be highly relevant for libraries that seek to serve the multicultural background of those attending universities. ${ }^{24}$ Moreover, Vega García implies that "racial and ethnic materials" are significant not only to the communities they represent but also to the students at large as they develop into global citizens. ${ }^{25}$

Several scholars have addressed cultural diversity in academic libraries. Roberto G. Trujillo and David C. Weber, advising on 10 initiatives to foster cultural diversity in academic libraries, promote educating students on the value of considering the "ideas" of people around the world. ${ }^{26}$ Similarly, Hilary H. Thompson et al., investigating the borrowing needs of Latin American materials by users of the Big Ten Academic Alliance, suggest that publications from Latin American and other countries around the globe enhance diversity and promote a global vision while meeting the teaching and research needs of universities. ${ }^{27}$

Collecting international materials including those of Latin American countries has challenges. Authors identify costly shipping, complicated payment procedures, copyright laws, and licensing limitations. ${ }^{28}$ Purchasing books from Hispano-American countries poses similar challenges. However, these challenges do not diminish the need for diversity in universities' collections. Different authors attest to the need to advocate for collection materials that represent the whole spectrum of human knowledge beyond what is produced by the dominant society. ${ }^{29}$ On a similar note, Rita A. Marinko and Kristin H. Gerhard advocate for access to a wide representation of materials as a means for libraries to promote pluralism. ${ }^{30}$

\section{Lo Latinoamericano}

The concept of "lo latinoamericano" embodies an aspiration for diversity in a pluralistic collection that represents a wider spectrum of human knowledge. Literature professor Genara Pulido Tirado implies that "lo latinoamericano" is a search for identity that started in Hispano-American countries after their independence from European colonizers. ${ }^{31}$ Similar to "lo latinoamericano," Hispano-American literature offers the particular identities of authors as substantiated by the cultural and political landscape of their own countries. On the other hand, Latin Americanist Cecilia Pilicsek considers "lo latinoamericano" as a cultural phenomenon produced by the publishing factor, which disseminated worldwide the narrative style of magical realism as an expression of Latin-American culture. ${ }^{32}$ This trend spread during the 1960s and 1970s by the success of Latin-American boom writers, especially Gabriel Garcia Márquez and his novel Cien Años de Soledad published in 1967. Transculturation expert and writer Ángel Rama noted that the boom was instrumental in the diffusion and translation of Latin-American literature beyond Latin America. ${ }^{33}$

However, not all boom writers used magical realism in their work; they published novels with English modernist techniques aspiring to represent the complexities of their societies. ${ }^{34}$ Boom writers reached a wider audience than their predecessors because of the process of urbanization and increased formal education, which created a broader middle-class reading audience. ${ }^{35}$ In the case of Europe, there was an increased interest in Latin-American writers after the Cuban Revolution. ${ }^{36}$ Therefore, authors such as Gabriel García Márquez, Mario Vargas Llosa, Julio Cortázar, and Carlos Fuentes would come to represent a group of HispanoAmerican authors bringing a distinct literary phenomenon to countries outside Latin America.

Citing the Argentinian writer Julio Cortázar, Rama postulates that the boom is not only a market-driven moment. ${ }^{37}$ Although the boom started in Brazil and kept progressing in Argentina and Mexico, Latin Americanist Anadeli Bencomo infers that publishers in Barcelona drove the 
international visibility of boom writers. ${ }^{38}$ However, after the boom, publishing houses moved to a centralized global model, causing the Hispano-American literature to lose identity. Bencomo refers to the "novela global" as a European perspective based on individualism where publishing houses in Spain are promoting the Hispano-American narrative as a product of an international style of novel as a genre. However, this forced authors to sacrifice other genres, such as "el cuento" and "la crónica," that have a powerful Latino-American tradition. ${ }^{39}$

Therefore, because these factors appear to affect the type of published materials, libraries may choose to recognize the value of these monographs by making efforts to purchase books that have been edited by Hispano-American editors conserving the original cover of the book and essence of the "lo latinoamericano." Bringing these books to the collection may not only reduce collection gaps but also connect researchers and students to a much wider array of Hispano-American literary input, building cultural capital in the process.

In addition, cultural capital and social capital may resonate in the publishing industry. Hispanic-American presses may demonstrate an accumulation of knowledge and cultural goods, as embodied in books, which they could share with university libraries in the United States to assert these presses' value and cultural capital in society. Similarly, social capital may positively influence the extent to which Hispano-American presses may build networks that would be mutually beneficial for them, book distributors, and university libraries in the United States. Finally, acquiring books published in Hispano-American countries advances diversity in university collections promoting inclusive and pluralistic collections.

\section{Methodology}

To quantify the extent to which university libraries are purchasing books published in HispanoAmerican countries, this study used WorldCat's "expert search" feature (OCLC FirstSearch) to determine the number of books, published in all 19 Hispano-American countries and Spain from 2014 to 2018, that are held in 88 university libraries in the United States and the Library of Congress. The 88 universities are member institutions of the Association of Research Libraries, as well as OCLC (Online Computer Library Center) library members. ${ }^{40}$ Each search featured the country of publication with its corresponding country code and indexed in "country of publication phrase $(\mathrm{cp}=)$." The search was limited to year of publication set between 2014 and 2018, language "Spanish," and number of libraries "all." The search was also limited to "books," "any audience," "any content," and "any format." The search was not limited to specific genres or call numbers, to obtain as much data as possible about holdings of books published in Hispano-American countries. Because universities tend to have several campuses, each search corroborated the corresponding library code's zip code with that of the Spanish department or program location for a given university. The data was collected in July 2019.

The data collected through OCLC's FirstSearch had some limitations. OCLC displays only records that university libraries have uploaded or shared with this cooperative organization. The OCLC data in this research thus has to be examined considering the possibility that there is incomplete information shared with OCLC by the member university. OneSearch was also considered as a search platform originally. However, this platform does not facilitate a search by country of publication, as WorldCat does.

The 88 universities studied represent public and private institutions with a variety of student enrollment. Enrollment information was taken from universities' online data enrollment page. Table 1 lists the OCLC country code for the countries included in this study. The total en- 
rollment for the 88 universities was collected to consider the correlation, if any, between university size and number of holdings of books published in Hispano-American countries in this time frame. Finally, the authors collected data on whether these universities offer a graduate program covering any Latin American or Hispano-American topic. Data collected was organized in a spreadsheet. To avoid confusion with acronyms, university libraries are designated using their OCLC library code.

\section{Results}

\section{Representation of Hispano-}

\begin{tabular}{|l|c|l|c|}
\hline \multicolumn{4}{|c|}{ TABLE 1 } \\
\hline OCLC Country Code \\
\hline Argentina & Code & Country & Code \\
\hline Bolivia & ag & Honduras & ho \\
\hline Chile & bo & Mexico & $\mathrm{mx}$ \\
\hline Colombia & $\mathrm{cl}$ & Nicaragua & $\mathrm{nq}$ \\
\hline Costa Rica & $\mathrm{ck}$ & Panama & $\mathrm{pn}$ \\
\hline Cuba & $\mathrm{cr}$ & Paraguay & $\mathrm{py}$ \\
\hline Dominican Republic & $\mathrm{cu}$ & Perú & $\mathrm{pe}$ \\
\hline Ecuador & ec & Puerto Rico & $\mathrm{pr}$ \\
\hline El Salvador & $\mathrm{es}$ & Venezuela & ve \\
\hline Guatemala & $\mathrm{gt}$ & Spain & $\mathrm{sp}$ \\
\hline
\end{tabular}

\section{American Presses}

Figure 1 shows that, of the 19 Hispano-American countries, Mexican, Argentinian, Colombian, Peruvian, Chilean, and Cuban presses have the greatest book holding representation in the university libraries covered, with holdings that each exceed 20,000. Figure 1 also shows an

\begin{tabular}{|c|c|c|c|}
\hline \multicolumn{4}{|c|}{$\begin{array}{c}\text { FIGURE } 1 \\
\text { Country of Books Published between } 2014 \text { and } 2018\end{array}$} \\
\hline Spain & & \multirow{3}{*}{115,436} & \multirow[t]{20}{*}{201,336} \\
\hline Mexico & 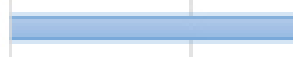 & & \\
\hline Argentina & $\square$ & & \\
\hline Colombia & 33,835 & & \\
\hline Peru & 31,286 & & \\
\hline Chile & 28,037 & & \\
\hline Cuba & $\square 22,511$ & & \\
\hline Venezuela & 19,925 & & \\
\hline Uruguay & 18,374 & & \\
\hline Ecuador & $\square \quad 14,683$ & & \\
\hline Boliva & 13,765 & & \\
\hline Costa Rica & $\square 9,898$ & & \\
\hline Guatemala & - 8,992 & & \\
\hline Puerto Rico & $\square, 740$ & & \\
\hline Dominican Republic & 7,668 & & \\
\hline Nicaragua & 5,486 & & \\
\hline Paraguay & 5,413 & & \\
\hline El Salvador & 5,172 & & \\
\hline Panama & 3,567 & & \\
\hline Honduras & 3,544 & & \\
\hline
\end{tabular}


ample margin of difference in the holdings published in the top two Hispano-American countries (Mexico and Argentina), and those published in the remaining 17 countries. Nonetheless, holdings published by Iberian (Spain) presses surpasses all those from Hispano-American countries by a large difference. The holdings from Iberian presses even exceed Mexican presses, which presents the second largest representation, by over 85,000 titles. Similarly, there is a difference of almost 198,000 holding counts between Iberian and Honduran presses, the latter with the lowest book holding representation in the university libraries studied. This illustrates disparities in scale.

Figure 2 shows the total number of Hispano-American holdings versus the university enrollment for each library $(n=88)$. Each point represents a library, and the position of that point on the graph is determined by the enrollment of the university where the library is located (x-axis) and the library's total number of books from Hispano-American countries (y-axis). The correlation between university enrollment and total Hispano-American holdings is -0.03 , which means there is close to zero correlation between the size of a university and its Hispano-American holdings. Figure 2 also suggests that some of the smallest and medium-sized universities own more books from Hispano-American holdings than the largest universities. Of the 88 universities studied, 81 offer a graduate program in Spanish. In addition, 84 universities indicate that they provide as an area of study or track: Latin-American studies, Latin-American literatures, Latino studies, Latino literature, Spanish-American, Hispanic southwest studies, cultures of the Americas, or Spanish-American literature. Nine universities provide programs in Spanish and/or majors and minors in Spanish, but they do not offer graduate degrees in Spanish.

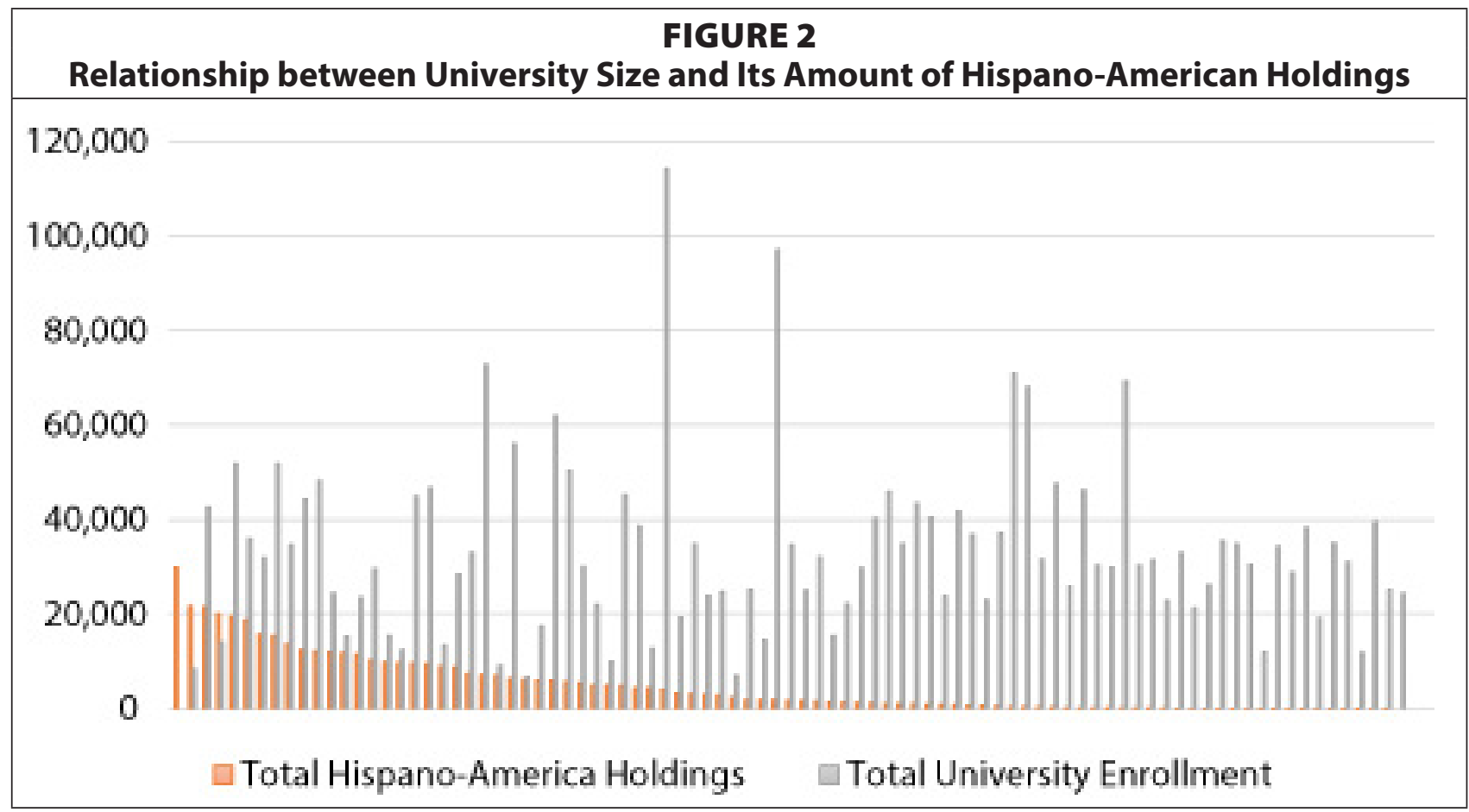

Table 2 shows the total number of books, published between 2014 and 2018, from Spain and 19 Hispano-American countries, which are held in 88 university libraries and the Library of Congress, organized in descending order of representation. Most of these university libraries (95 percent) represent universities that offer Latin-American studies in their programs. 
Only four universities do not state an explicit reference to a Latin-American program on their website. Table 2 also shows that 38 university libraries (43\%) hold less than 1,000 books published in Hispano-American presses. Twenty-two percent of university libraries hold less than 100 books published in Hispano-American countries.

\begin{tabular}{|c|c|c|c|c|c|c|c|c|}
\hline \multicolumn{9}{|c|}{$\begin{array}{c}\text { TABLE } 2 \\
\text { Total Books Published in Spain and Hispano-America Held in } 88 \text { University Libraries and } \\
\text { Library of Congress }\end{array}$} \\
\hline $\begin{array}{l}\text { Library } \\
\text { Code }\end{array}$ & Spain & $\begin{array}{l}\text { Hispano- } \\
\text { American }\end{array}$ & $\begin{array}{l}\text { Library } \\
\text { Code }\end{array}$ & Spain & $\begin{array}{l}\text { Hispano- } \\
\text { American }\end{array}$ & $\begin{array}{l}\text { Library } \\
\text { Code }\end{array}$ & Spain & $\begin{array}{l}\text { Hispano- } \\
\text { American }\end{array}$ \\
\hline DLC & 23,349 & 29,766 & PAU & 6,159 & 4,896 & NJR & 68 & 388 \\
\hline PUL & 11,436 & 21,642 & RBN & 3,969 & 4,878 & OSU & 949 & 305 \\
\hline CUY & 7,334 & 21,496 & AZU & 1,670 & 4,741 & IAY & 2,053 & 232 \\
\hline LRU & 4,578 & 20,112 & GUA & 1,516 & 4,358 & CSL & 195 & 226 \\
\hline IXA & 2,718 & 19,309 & TJC & 1,300 & 4,241 & LDL & 123 & 206 \\
\hline HUL & 8,412 & 18,643 & IUL & 2,427 & 4,004 & TXH & 117 & 167 \\
\hline ZCU & 10,618 & 15,736 & DGU & 1,622 & 3,373 & AUM & 286 & 161 \\
\hline ZYU & 8,105 & 15,367 & COD & 2,362 & 3,097 & MUU & 192 & 106 \\
\hline PIT & 3,177 & 13,794 & CRU & 651 & 2,888 & TXA & 231 & 103 \\
\hline GZM & 3,600 & 12,480 & VA@ & 2,073 & 2,743 & KUK & 273 & 92 \\
\hline UIU & 7,657 & 12,102 & RCE & 6,992 & 2,265 & NTE & 21 & 83 \\
\hline IQU & 825 & 11,887 & JHE & 2,178 & 1,774 & SYB & 206 & 82 \\
\hline NDD & 3,221 & 11,766 & BXM & 281 & 1,738 & UUM & 60 & 49 \\
\hline $\mathrm{COO}$ & 3,189 & 11,452 & UPM & 1,199 & 1,723 & YSM & 84 & 39 \\
\hline NOC & 3,420 & 10,340 & WAU & 2,021 & 1,667 & KLG & 25 & 39 \\
\hline EMU & 3,976 & 9,767 & CUT & 641 & 1,555 & NRC & 33 & 33 \\
\hline IND & 2,479 & 9,599 & UCW & 154 & 1,512 & SUC & 95 & 25 \\
\hline CLU & 4,333 & 9,590 & WTU & 427 & 1,383 & CWR & 74 & 23 \\
\hline EYM & 4,389 & 9,440 & INU & 762 & 1,245 & AAA & 58 & 23 \\
\hline YUS & 11,963 & 8,900 & OKU & 733 & 1,109 & BOS & 73 & 20 \\
\hline KKU & 2,251 & 8,729 & TEU & 1,548 & 1,090 & TKN & 72 & 19 \\
\hline $\mathrm{NUI}$ & 3,285 & 7,401 & CIN & 1,626 & 946 & KSU & 5 & 17 \\
\hline AZS & 1,719 & 7,045 & OUN & 152 & 905 & DGW & 24 & 15 \\
\hline CUS & 665 & 7,008 & IPL & 149 & 901 & IWA & 27 & 13 \\
\hline FUG & 1,252 & 6,215 & UMC & 273 & 860 & LUU & 28 & 9 \\
\hline DRB & 3,957 & 6,190 & DLM & 180 & 851 & RRR & 368 & 8 \\
\hline FQG & 799 & 6,003 & FDA & 1,109 & 829 & AML & 19 & 7 \\
\hline MNU & 1,912 & 5,952 & CUI & 686 & 657 & EYW & 3 & 1 \\
\hline EEM & 3,124 & 5,650 & ORU & 600 & 647 & OKS & 8 & 0 \\
\hline CUV & 1,221 & 5,372 & VRC & 1,142 & 440 & & & \\
\hline
\end{tabular}

Figure 3 shows the total number of books published in Spain and held in each library. Thirty-eight percent of these universities have more books published in Spain than in the ag- 
gregated Hispano-American countries. In a majority of libraries, Spain represents more than 25 percent of the library's offerings compared with the aggregate of the 19 Hispano-American countries. The horizontal dashed line represents the 50 percent mark so a library whose bar is at that line would have 50 percent of its Spanish books from Spain and 50 percent of its books from the 19 Hispano-American countries. A library whose bar is above that dashed line has more than half its Spanish-language books from Spain, the rest of the percentage coming from the Hispano-American countries.

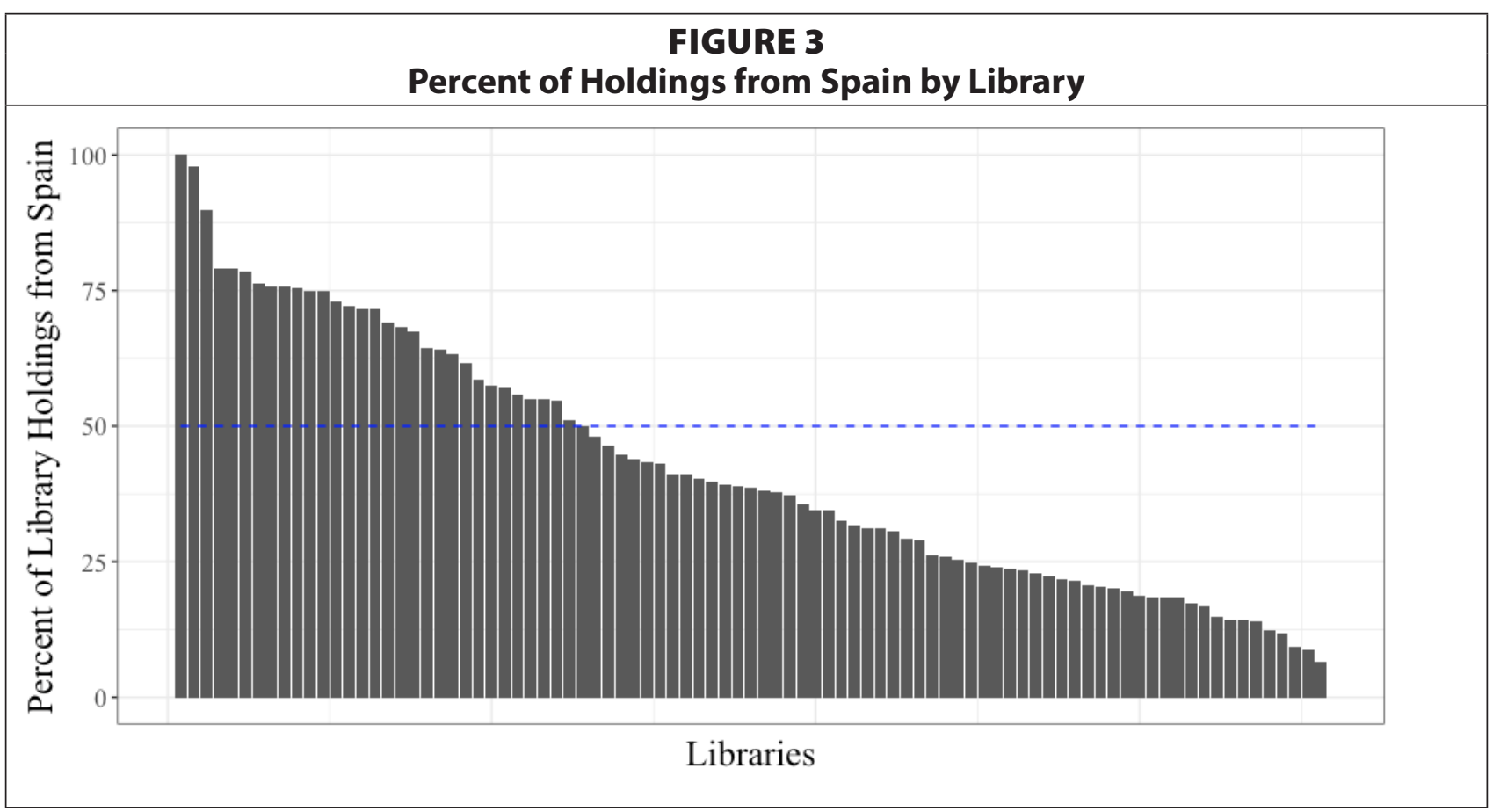

Table 3 shows the university libraries with the top 15 holding of books published in HispanoAmerican countries and the Library of Congress (DLC). All of these universities have a graduate program that covers a Latin-American topic; 14 of these universities have a $\mathrm{PhD}$ program, and one, University of Illinois at Urbana-Champaign(UIU), offers a master's as its highest degree. Their total university enrollment varies from small to medium-sized universities, although the University of Texas (IXA) and New York University (ZYU) could be considered large universities based on their enrollment. The largest enrollment presented in the 88 universities (not shown in table 3) are held by the following schools: University of Minnesota (MNU) (61,975 total enrollment), Arizona State University (AZS) (72,709), and the Indiana University at Bloomington (IUL) $(114,160)$.

\begin{tabular}{|l|c|c|c|}
\hline \multicolumn{4}{|c|}{ ComLE 3 } \\
\hline Library Code & Hispano-American Holdings & Total Enrollment & Graduate Program \\
\hline DLC & 29,766 & $\mathrm{n} / \mathrm{a}$ & $\mathrm{n} / \mathrm{a}$ \\
\hline PUL & 21,642 & 8,374 & $\mathrm{PhD}$ \\
\hline CUY & 21,496 & 42,519 & $\mathrm{PhD}$ \\
\hline LRU & 20,112 & 14,062 & $\mathrm{PhD}$ \\
\hline IXA & 19,309 & 51,832 & $\mathrm{PhD}$ \\
\hline HUL & 18,643 & 36,012 & $\mathrm{PhD}$ \\
\hline
\end{tabular}




\begin{tabular}{|l|c|c|c|}
\hline \multicolumn{4}{|c|}{ Comparison of Holdings and Enrollment } \\
\hline Library Code & Hispano-American Holdings & Total Enrollment & Graduate Program \\
\hline ZCU & 15,736 & 32,032 & PhD \\
\hline ZYU & 15,367 & 51,847 & PhD \\
\hline PIT & 13,794 & 34,580 & PhD \\
\hline GZM & 12,480 & 44,411 & PhD \\
\hline UIU & 12,102 & 48,216 & Master \\
\hline IQU & 11,887 & 24,393 & PhD \\
\hline NDD & 11,766 & 15,192 & PhD \\
\hline COO & 11,452 & 23,600 & PhD \\
\hline NOC & 10,340 & 29,469 & PhD \\
\hline
\end{tabular}

Figure 4 displays the number of university libraries $(n=88)$ that hold zero books published in the specified Hispano-American country or Spain, from 2014 to 2018. The data shows the holding disparity university libraries have among the different Hispano-American countries. This disparity indicates that the representation of books published in Hispano-American countries is highly uneven in university libraries. The data also exposes that books published in Spain are always represented in university libraries' collections, while 49 percent of university libraries have zero holdings of books published in at least one Hispano-American country.

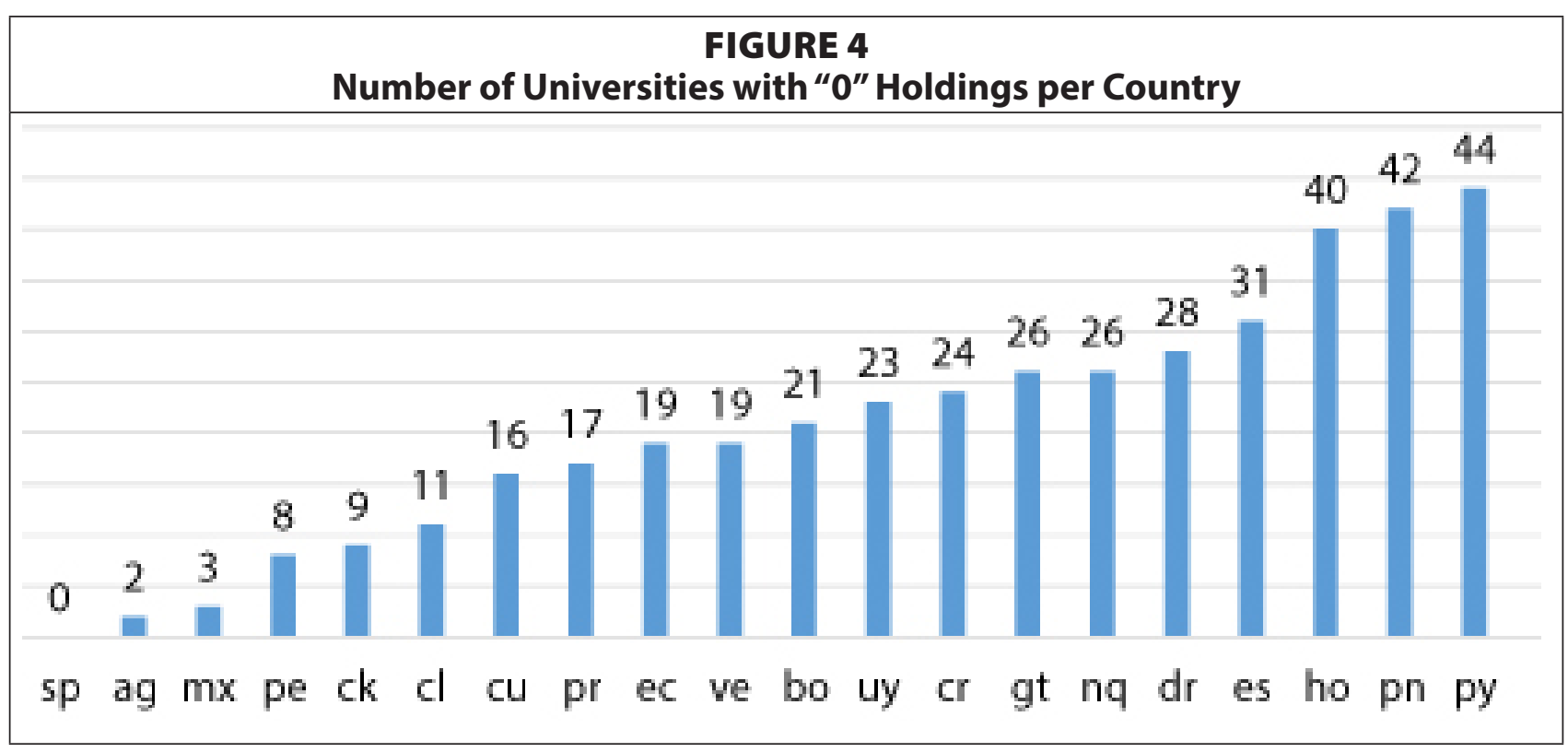

Figure 5 displays the total number of Spanish-language books that are held in university libraries in the five countries with the largest representation, in the time period studied. While Peruvian and Colombian presses have a similar number of holdings, Argentinian presses have twice the number of holdings in university libraries. As shown in figure 6, Iberian presses surpass Peruvian and Colombian presses in nearly 100 percent of the libraries, Argentinian presses in 95 percent, and Mexican presses in 77 percent. Similarly, Mexican presses exceed Peruvian and Colombian presses in 94 percent of the libraries, Argentinian presses almost 89 percent, and Spanish presses in 22 percent of the libraries. 

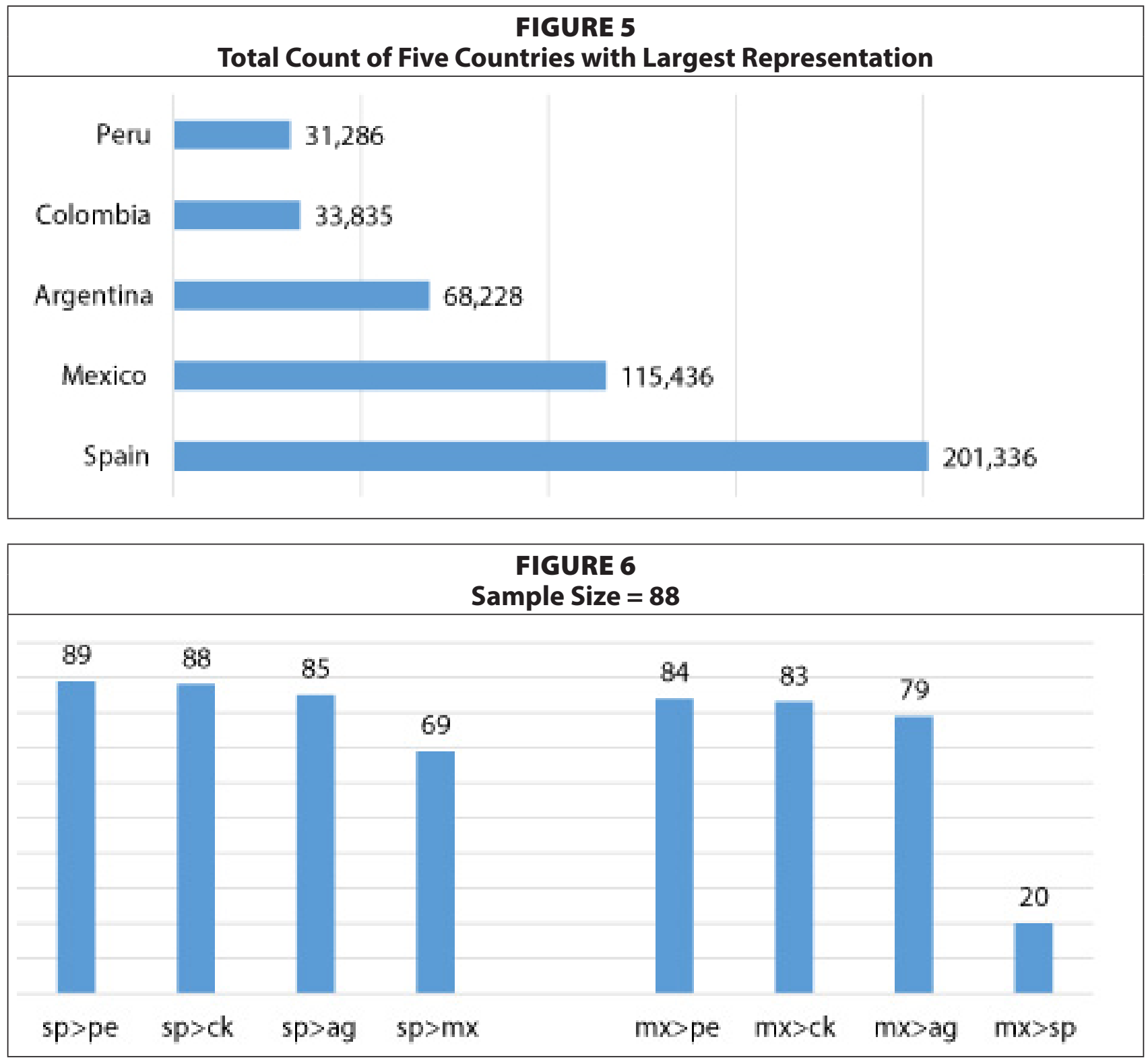

\section{Discussion}

\section{Cultural Capital, Social Capital, and Lo Latinoamericano}

Cultural capital resonates with the inherent value of acquiring books that are not readily available through mainstream vendors used by university libraries. When university libraries provide access to literature that represent the cultural, political, artistic, and social sentiment of a nation, it bestows the capability to gain knowledge that is paramount for students to understand the complexities of the world as a pluralistic place where many cultures exist.

Books such as "Paloma Torcaza" published in Perú by Editorial Crecer, provides one example of an Andean short novel written by the Peruvian writer Sócrates Zuzunaga Huaita, winner of multiple literary awards including the Primer Premio de Literatura Quechua. Although "Paloma Torcaza" is considered juvenile literature, it touches on subjects of social injustice, rape, and literary symbols that are representatives of Andean literature. According to WorldCat, one U.S. university holds this book. The title "Hilando en la Memoria," published by Editorial Cuarto Propio in Chile, is another example of a book with literary value rarely 
represented in university libraries in the U.S. This book is a compilation of poems written in Mapudungun and Spanish by 14 Mapuche women. In fact, Latin American indigenouslanguage publications are one important area of literature that is usually found in HispanoAmerican publishing houses instead of the American and the peninsular counterpart.

Social capital is a type of capital that has gained tremendous importance in the 21st century. The concepts of social networks and "structure of relations," as defined by Coleman, may be a needed answer to create relationships among book vendors in different parts of the world. This network of relationship has the potential to improve the reach to literature produced in Hispano-American countries that is not usually offered by mainstream vendors and publishers.

Social capital could also improve the very factors that obstruct business with vendors and publishers in Hispano-American countries. For example, a relationship between a mainstream book vendor and a Hispano-American vendor or publisher could reduce shipping costs and potentially provide motivation and means to upgrade websites and methods of communication. Should such relationship among book distributors from different countries and alternative and nontraditional publishing houses flourish, then cultural capital could also increase for those university libraries benefiting from this relationship. Ideally, the fruit of this social capital would allow university libraries to enhance cultural capital in their students and other university members by providing access to a wide array of Hispano-American literature that otherwise may be absent from universities in the U.S.

However, one may wonder why it is relevant to have access to a wide array of literature published in Hispano-American countries. The concept of "lo latinoamericano" as interpreted by Pulido may help librarians understand that Hispano-American authors offer a national identity and inside understanding on the issues surrounding their own countries that may differ from the accounts of foreign authors writing about those topics. For instance, Hispano-American authors are more likely aware of the struggles of marginalized communities (such as Quechua and Mapuche nations) in their own countries. This is not to say that the work of foreign researchers lacks merit. However, if the main spectrum of Spanish literature in university libraries in the U.S. is represented by non-Hispano-American authors, then our universities have access to a much smaller portion of the canon published in Hispano-America.

Ultimately, universities seek to enlarge the intellectual horizons of their students by exposing them to a wide variety of ideas and the cultural diversity of different nations. University libraries may contribute to this goal by providing pluralistic collections that may help enable students to become global learners.

\section{Are University Libraries in the United States Building Spanish-Language Collections That Consider Literature Representing All Hispano-Speaking Countries?}

An examination of Spanish-language book holdings in 88 university libraries in the United States and the Library of Congress shows that these libraries purchase more books published in Spain and Mexico than books published in any of the other Hispano-American countries. Although the data collected through WorldCat's FirstSearch may not be completely accurate (because it relies on self-reporting from the universities), it appears evident that there may be an imbalance in the manner in which university libraries build Spanish-language collections. 
Considering that nearly all of the university libraries in this study serve universities that offer a track or at least a course that covers a Latin American topic, the inequality of representation affecting books published in Hispano-American countries may influence scholarship, course curricula, and access to books. Access is a relevant aspect of this conversation, since presses in Spain and well-known distributors or vendors may not carry all the canon of books written by Hispano-American emerging authors or even recognized authors.

A collection development librarian at the University of Colorado Boulder (COD) explained that purchasing books from vendors in Spain was more convenient. The librarian also stated that Iberian vendors tend to give better purchasing deals and better offers. ${ }^{41}$ These vendors also respond to questions and email messages promptly and may process purchases more expeditiously, in his experience. This does not mean that distributors for Hispano-American countries are unable to offer the same level of service. However, in the case of COD, most vendors for Hispano-American publications are based in the United States and may have delays in inventory, which may delay communication and the acquisition process. These issues may help clarify why other collection librarians would prefer and choose Iberian vendors, resulting in the collection gaps found in this study.

The uneven representation of books published in Hispano-American countries may be explained by considering book budget distribution. University libraries may be allocating more money to purchase books published in a specific Hispano-American country than others. To illustrate, COD allocates $\$ 1,500$ to purchase books published in Colombia and $\$ 400$ to purchase books published in Paraguay. This budget distribution could explain the reason why COD holds more books published in Colombia than Paraguay.

One could argue that the size of the university-seen in total enrollment-may affect the book budgetary power of a university. Although this study does not have information on the amount of money each university allocates to their Spanish-language collections, figure 2 shows that there is no correlation between the size of a university and the number of books from Hispano-American presses held in a respective library. In fact, data from this study shows that small to medium-sized universities tend to have more books published in Hispano-American countries than the universities with larger enrollment.

Another possible explanation for the unbalanced representation is the area of research pursued by professors and graduate students in different universities. This may elucidate the reason why Boston University (BOS), for example, holds more books from Mexico than from any other country. If an area of research covers a topic that has direct relationship with a country, such as "cultural biases in Chilean social stratification," one could safely predict that the university library representing this researcher may be purchasing books by Chilean authors who are authoritative in this subject and whose books may have been first published in Chile.

Finally, one may theorize that a paucity of publishing houses in Hispano-American countries may contribute to their insufficient representation in university libraries. However, an online search found that several Hispano-American countries have a rich publishing house landscape, which includes university presses, established presses, and independent presses, in countries such as Chile, Argentina, Colombia, Paraguay, Uruguay, Perú, Honduras, and Venezuela. Data also shows that university libraries have purchased books representing each of the Hispano-American countries considered in this study. Therefore, the issue is more related to university libraries focusing on purchasing books published in Mexico and Spain, than a lack of presses in the Hispano-American countries covered. 


\section{Recommendations}

Every university library has its own set of collection development policies and procedures that guide collection development librarians and subject specialists to use established criteria to purchase books. Similarly, subject specialists normally have wide discretion to determine how book budgets are distributed among their collections. Regardless of the type of collection development program, such as approval plans (contracts based with distributors), firm orders, (direct requests from patrons), or purchase request suggestions (patrons suggesting a library purchase through an online form), subject specialists are making decisions concerning the collection and the budget. Therefore, it is advisable for subject specialists to be acquainted with the appropriate collection development criteria and have a vision that not only represents the collection needs of departments and constituents but also delineates current sociocultural changes and future research agendas.

Mindful of this vision, subject specialists should consider the benefits of supporting a balanced Spanish-language collection that includes books published in Hispano-American countries. An inclusive collection is preferable because it considers a wider array of ideas, writers, and geographical zones, which may provide better support for course curriculum and opportunities for research. Similarly, a collection that contains books published in Hispano-American countries may close a gap in collection representation and may have a broader appeal to users offering not only a more comprehensive collection but also opportunities for student success. Ultimately, by expanding the purchasing practices to include books published in Hispano-American countries, university libraries are enhancing user opportunities to acquire global learning and global knowledge. This study shows that nearly all of the analyzed universities offer programs related to Latin-American studies. Therefore, it appears reasonable to address the lack of HispanoAmerican presses represented in some university libraries' Spanish-language collections.

This research does not imply that publishing houses from Spain and Mexico have diminished value for Spanish-language collections in academic libraries. On the contrary, both of these countries have a robust publishing tradition, which is greatly valued in university libraries. However, if canonical books from Hispano-American authors, which are of relevance to academic libraries, could only be found in Hispano-American presses, then there should be motivation to include these presses in approval plans. Similarly, subject specialists should welcome submissions from patrons who are requesting books published in Hispano-American presses using the Suggest a Purchase program.

Another recommendation, which some university libraries have implemented, involves building consortia to share funds to purchase different books to complement their collections. For example, one university library could purchase books published in Chile, while another could purchase books published in Paraguay, sharing these resources between themselves. This approach pools resources to obtain a broader representation of books, minimizing the overlapping of titles. Such a program also implements a regionally based collection development perspective, which may respond to academic trends much faster than building collections with funds from only one university library. However, from the point of view of university libraries and their Spanish-language collections, it is essential to discern whether it is more relevant to grow an in-house collection or share resources to grow a region-based collection.

Approval plans may play a role in the advancement of inclusive Spanish-language collections. It is recommended that subject specialists and collection development librarians assess approval plans and how well these plans translate into well-balanced and inclusive repre- 
sentation of books. In addition, subject specialists should gather a list of Hispano-American presses, including academic and independent presses, and presses that publish artists and experimental books, and share the list with collection development librarians in charge of Spanish-language collections.

Subject specialists could also create a funds structure that supports the inclusion of books published in different Hispano-American countries. Approval plan contracts should include categories that encompass specific collection needs. When these contracts are drafted with overbroad guidelines, lacking specificity, academic libraries risk receiving the same books as other academic libraries, thus invalidating the growth of a Spanish-language collection that complements wide-reaching scholarship. Since approval plans may be as comprehensive as to include types of books that vendors should and should not include, a conscientious and inclusive narrative of these plans could delineate more than general guidelines (comprehensive literature, cultural studies, and literary criticism). A more inclusive approach will ensure that vendors provide a fairer representation of books published in Hispano-American countries. This could be achieved by relying on social capital to build relationships with vendors and Hispano-American publishers. This relationship has the capability to broaden access to a wider scope of literature and thus foster cultural capital.

\section{Conclusion}

The assessment of books published in Hispano-American presses, between 2014 and 2018, and held in 88 university libraries in the United States, shows a lack of representation of these presses. While large conglomerates and renowned publishing houses publish important authors whose works advance Spanish-language collections in universities, it may be the smaller presses in Hispano-American countries that publish emerging authors and even the complete works of consequential authors that may be relevant for academic libraries in the United States.

One may argue that the makeup of the publishing industry market in the academic sector inhibits the sharing of a particular knowledge that is provided by editors and presses of authors' country of origin. The formation of a symbiotic relationship between Hispano-American houses and Iberian presses to publish books that retain their natural and original value would capture broader benefits for both these actors and the receiver (academic libraries in the United States). This relationship would also lead to an increase in social capital, a network of publishers and book vendors from Hispano-American countries, Spain, and the U.S, who would collaborate so university libraries have broader access to books published in Hispano-American countries.

This collaboration would be advantageous to all parties involved and would ultimately promote cultural capital by facilitating access to a larger canon of Hispano-American authors to the university libraries and their users. This wider representation of Hispano-American authors and literary genres may have a positive impact on the creation of curriculums, which could lead to more opportunities for global learning. Finally, a more inclusive representation could also extend professors' and students' research interests to a wider array of topics and ideas embracing inclusion and diversity, two important factors for university libraries in the Unites States.

\section{Notes}

1. American Library Association (ALA), "Selection Criteria" (2018), available at www.ala.org/tools/challengesupport/selectionpolicytoolkit/criteria. 
2. ALA, "Selection Criteria."

3. Rhalee A. Hughes, "A Means to Measure," Publishing Research Quarterly 21, no. 3 (2005): 12-13, https://doi. org/10.1007/s12109-005-0037-2.

4. Brigitte Ouvry-Vial, "Small and Big Publishers in France: Is Literature a Rare Species?" Publishing Research Quarterly 19, no. 1 (2003): 32, https://doi.org/10.1007/s12109-003-0021-7.

5. Ouvry-Vial, "Small and Big Publishers in France," 32.

6. Ouvry-Vial, "Small and Big Publishers in France," 37.

7. Ouvry-Vial, "Small and Big Publishers in France," 39.

8. Pierre Bourdieu, "A Conservative Revolution in Publishing," Translation Studies 1, no. 2 (2008): 138, https:// doi.org/10.1080/14781700802113465.

9. Bourdieu, "A Conservative Revolution in Publishing."

10. See Gabriela Dalla Corte, "Mercado del Libro y Empresas Editoriales entre el Centenario de las Independencias y la Guerra Civil Española: La Editorial Sudamericana," Revista Complutense de Historia de América 36 (2010): 282-83, https://doi.org/10.5209/rev_RCHA.2010.v36.12; Hughes, "A Means to Measure,"13; Ouvry-Vial, "Small and Big Publishers in France," 32; Thomas Woll and Dominique Raccah, "The World of Publishing," in Publishing for Profit: Successful Bottom-Line Management for Book Publishers" (Chicago, IL: Chicago Review Press, 2014), 7 .

11. Ouvry-Vial, "Small and Big Publishers in France," 32.

12. Luca Pareschi, "How I Met My Publisher: Casual and Serial Intermediaries in First-Time Authors' Publication in the Italian Literary Field," Cultural Sociology 9, no. 3 (2015): 416, https://doi.org/10.1177/1749975515590632.

13. Bourdieu, "A Conservative Revolution in Publishing," 138.

14. Bourdieu, "The Forms of Capital," in Handbook of Theory of Research for the Sociology of Education, ed. J.E. Richardson, trans. Richard Nice (Westport, CT: Greenwood Press, 1986), 46-51.

15. Bourdieu, "The Forms of Capital," 47.

16. C. Clayton Childress, "Decision-Making, Market Logic and the Rating Mindset: Negotiating BookScan in the Field of US Trade Publishing," European Journal of Cultural Studies 15, no. 5 (2012): 604-20, https://doi. org/10.1177/1367549412445757.

17. Nicki Lisa Cole, "What Is Cultural Capital? Do I Have It?" ThoughtCo., https://www.thoughtco.com/whatis-cultural-capital-do-i-have-it-3026374 [accessed 17 June 2019].

18. Seok-Woo Kwon and Paul S. Adler, "Social Capital: Maturation of a Field of Research," Academy of Management Review 39, no. 4 (2014): 412, https://doi.org/10.5465/amr.2014.0210.

19. James S. Coleman, "Social Capital in the Creation of Human Capital," American Journal of Sociology 94 (1988): S98, https://doi.org/10.1086/228943.

20. Ian Falk, "Human Capital and Social Capital: What's the Difference?" Adult Learning Commentary 28 (2000).

21. Marina Tulin, Bram Lancee, and Beate Volker, "Personality and Social Capital," Social Psychology Quarterly 81, no. 4 (2018): 297, https://doi.org/10.1177/0190272518804533.

22. Tulin, Lancee, and Volker, "Personality and Social Capital," 298.

23. Susan A. Vega García, "Racial and Ethnic Diversity in Academic Library Collections: Ownership and Access of African American and U.S. Latino Periodical Literature," Journal of Academic Librarianship 26, no. 5 (2000): 311, https://doi.org/10.1016/S0099-1333(00)00137-3.

24. Vega García, "Racial and Ethnic Diversity in Academic Library Collections."

25. Vega García, "Racial and Ethnic Diversity in Academic Library Collections," 319.

26. Roberto G. Trujillo and David C. Weber, "Academic Library Responses to Cultural Diversity: A Position Paper for the 1990s," Journal of Academic Librarianship 17, no. 3 (1991): 158.

27. Hilary H. Thompson et al., "Borrowing Latin American Materials in the Big Ten Academic Alliance: A Case Study for Consortial Data Analysis," College E Research Libraries 80, no. 6 (2019): 768-69, https://doi.org/10.5860/ crl.80.6.766.

28. Thompson et al., "Borrowing Latin American Materials in the Big Ten Academic Alliance," 769; Manual Ostos and Lisa Gardinier, "Spanish-Language Print Materials within Academic Consortia: Assessing the Impact of Resource Sharing in Two Academic Libraries," Journal of Academic Librarianship 44, no. 2 (2018): 295, https://doi. org/10.1016/1.acalib.2017.12.005.

29. Deborah M. LaFond, Mary K. Van Ullen, and Richard D. Irving, "Diversity in Collection Development: Comparing Access Strategies to Alternative Press Periodicals," College \& Research Libraries 61, no. 2 (2000): 137, https:// doi.org/10.5860/crl.61.2.136; Camila A. Alire and Frederick J. Stielow, "Minorities and the Symbolic Potential of the Academic Library: Reinventing Tradition," College \& Research Libraries 56, no. 6 (1995): 516, https://doi.org/10.5860/ crl_56_06_509; Dominique Daniel, “Elusive Stories: Collecting and Preserving the Foreign-Language Ethnic Press in the United States," Serials Review 45, no. 1/2 (2019): 20, https://doi.org/10.1080/00987913.2019.1610148. 
30. Rita A. Marinko and Kristin H. Gerhard, "Representations of the Alternative Press in Academic Library Collections," Research \& College Libraries 59, no. 4 (1998): 363, https://doi.org/10.5860/crl.59.4.362.

31. Genara Pulido Tirado, "Los Orígenes de la Latinoamericano y la Función del Intelectual en la Concepción de Fernández Retamar: Arielismo vs. Calibanismo," Estudios Humanísticos. Filología no. 31 (2009): 247.

32. Cecilia Policsek, "El Forjamiento de 'Lo Latinoamericano' en Moldes Editoriales: El Caso Rumano en el Periodo 2004-2015," Noephilologus 103, no. 1 (2019): 85, https://doi.org/10.1007/s11061-018-9580-x.

33. Ángel Rama, “El Boom en Perspectiva,” Signos Literarios 1 (2005): 168.

34. Gerald Martin, "The Boom of Spanish-American Fiction and the 1960s Revolutions (1958-75,)" in A Companion to Latin American and Culture, vol. 53, ed. by Sara Castro-Klarén, (Malden, MA: Blackwell, 2008), 481.

35. Rama, 168.

36. Martin, 481.

37. Rama, 170.

38. Rama, La Novela en América Latina Panoramas 1920-1980, (Santiago, Chile: Ediciones Universidad Alberto Hurtado, 2013) Kindle edition; Anadeli Bencomo, "Geopolíticas de la Novela Hispanoamericana Contemporánea: en la Encrusijada entre narrativas Extraterritoriales e Internacionales," Revista de Crítica Literaria Latinoamericana 35, no. 69 (2009): 36.

39. Bencomo, 44.

40. Association of Research Libraries, "Member Institutions," https://www.arl.org/category/who-we-are/ member-institutions/ [accessed 25 October 2019].

41. Steven Selleck, conversation with the principal author, September 2019. 